\title{
Treatment of patients with HTLV-1-associated myelopathy with methotrexate
}

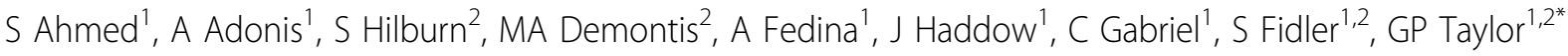 \\ From 16th International Conference on Human Retroviruses: HTLV and Related Viruses \\ Montreal, Canada. 26-30 June 2013
}

\section{Introduction}

The lifetime risk of developing HTLV-1 associated myelopathy (HAM) is $0.25-3 \%$. The main pathological feature is an immune-mediated response leading to chronic inflammation of the spinal cord. The optimal long term treatment has yet to be determined although clinical improvement with ciclosporin has been shown in a pilot study. Methotrexate, commonly used for autoimmune diseases, was introduced for the treatment of HAM at the National Centre for Human Retrovirology, London, $\mathrm{UK}$ as an alternative to ciclosporin.

\section{Methods}

A retrospective study of patients with chronic HAM treated with methotrexate. Primary outcomes are clinical both objective and subjective using routine clinic data. Secondary outcomes virological/immunological. Methotrexate was prescribed weekly at an initial dose of $7.5 \mathrm{mg}$ and a maximum dose of $15 \mathrm{mg}$ with weekly folic acid supplementation.

\section{Results}

Duration of methotrexate $4-59$ weeks. Generally well tolerated. Four haematological toxicities all grade $1 / 2$ and three liver toxicities two grade $3 / 4$ - one treatment discontinuation due to asymptomatic liver toxicity. Objective measure - Compared with baseline $-57.39 \mathrm{~s}$ (18.8-120) mean $10 \mathrm{~m}$ timed walk improved within 4 weeks $34.54 \mathrm{~s}(16.8-87), \mathrm{p}=0.0151$. The overall trend shows persistent improvement.

Subjective- Pain as measured on a Visual Analogue Scale improved over the duration of treatment with the greatest improvement occurring within the first 4 weeks of treatment. Virology and Immunological. T-cell

\footnotetext{
* Correspondence: g.p.taylor@imperial.ac.uk

${ }^{1}$ National Centre for Human Retrovirology, St Marys Hospital, London, UK

Full list of author information is available at the end of the article
}

activation markers, Th1/2 cytokine data and HTLV viral load data will be presented.

\section{Conclusions}

These preliminary data suggest that methotrexate may be beneficial for some patients with HAM and is a suitable candidate for a randomised controlled study.

\section{Authors' details}

National Centre for Human Retrovirology, St Marys Hospital, London, UK.

${ }^{2}$ Section of Infectious Diseases, Imperial College, London, UK.

Published: 7 January 2014

\section{doi:10.1186/1742-4690-11-S1-P33}

Cite this article as: Ahmed et al:: Treatment of patients with HTLV-1associated myelopathy with methotrexate. Retrovirology 2014 11(Suppl 1):P33.

\footnotetext{
Submit your next manuscript to BioMed Central and take full advantage of:

- Convenient online submission

- Thorough peer review

- No space constraints or color figure charges

- Immediate publication on acceptance

- Inclusion in PubMed, CAS, Scopus and Google Scholar

- Research which is freely available for redistribution

Submit your manuscript at www.biomedcentral.com/submit
} 